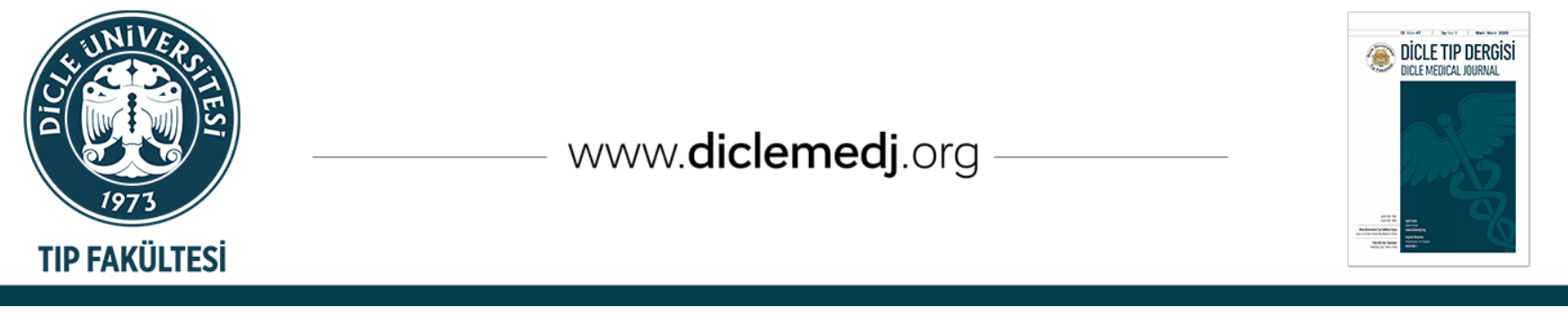

Original Article / Özgün Araştırma

\title{
Correlation of Malondialdehyde and Antioxidant Enzyme Levels with Peritonitis Severity in Patients with Generalized Peritonitis
}

\author{
Erkan Dalbaşı iD ${ }_{1}$, Ercan Gedik iD 2 , Abidin Tüzün iD 3 , Basra Deniz Obay 4 \\ 1 Memorial Hospital, Department of General Surgery, Diyarbakır, Turkey \\ 2 Dicle University,Faculty of Medicine,Department of General Surgery, Diyarbakır, Turkey \\ 3 Health Sciences University,Diyarbakır Gazi Yaşargil Education and Research Hospital, Department of General Surgery, Diyarbakır, Turkey \\ 4 Dicle University,Faculty of Medicine,Department of Physiology, Diyarbakır, Turkey
}

Received: 24.12.2019; Revised: 11.06.2020; Accepted: 11.06.2020

\begin{abstract}
Objective: Generalized peritonitis is fairly common with very high mortality of delayed diagnosis and treatment of infectious condition. In this study, we aimed to determine the effectiveness of malondialdehyde (MDA), superoxide dismutase (SOD), catalase (CAT) and C-reactive protein (CRP) levels in peritonitis severity.

Methods: This study was planned prospective and randomized. Study consisted of three groups. Each group had 50 patients. Group 1, patients with generalize peritonitis ; Group 2,patients with non-abdominal inflammatory disease; Group 3, healthy individuals as a control group. The venous blood samples from patients in group 1 and 2 were collected to determine MDA, SOD, CAT and CRP levels at the operation day. The same procedures repeated postoperative first and third day. Blood samples were collected once from group 3.0ne-way Anova test was used to compare average of intergroup parametric variables. Repeated Anova test was used to compare intragroup parameters.

Results: Demographic features and cause of laparatomy of all groups were evaluated. MDA values of group 1 in days 0 , 1st and 3rd compared with group 2 and group 3 the MDA values of group 1 were higher than group 2 and $3(p<0,0001)$. CAT values of group 1 in days 0,1 st and 3 rd were lower than group 2 and group 3 (p<0,0001). SOD values of group 1 and 2 in day 0 were lower than group $3(\mathrm{p}<0,0001)$. CRP values of group 1 in days 0,1 st and 3rd were higher than group 2 $(\mathrm{p}<0,0001)$.
\end{abstract}

DOI: 10.5798/dicletip.

Correspondence / Yazışma Adresi: Erkan Dalbasi, Memorial Hospital, Department of Surgery, Diyarbakır, Turkey e-mail: erkandalbasi@mynet.com 
Conclusions: It was concluded that SOD, CAT, MDA and CRP are useful parameters for the diagnosis and monitoring of generalized peritonitis severity.

Keywords: Generalized peritonitis, superoxide dismutase, catalase, malondialdehyde.

\section{Generalize Peritonitli Hastalarda Malondialdehit ve Antioksidan Enzim Seviyelerinin Peritonit Şiddeti ile Korelasyonu}

\section{Öz}

Amaç: Generalize peritonityaygın görülen, mortalitesi yüksek enfeksiyöz bir hastalıktır. Bu çalıșmada, generalize peritonitli hastalarda kanda malondialdehit (MDA),süperoksid dismutaz (SOD),katalaz (CAT) ve C-reaktif protein (CRP) düzeylerinin peritonit şiddetiyle korelasyonunu belirlemeyi amaçladık.

Yöntemler: Bu çalışma prospektif ve randomize olarak yapıldı. Çalışma üç gruptan oluşturuldu. Her grupta 50 hasta vardı. Grup 1,generalize peritonitli, Grup 2 ise peritonit bulgusu bulunmayan hastalardan oluşturuldu. Grup 3, sağlıklı bireylerden kontrol grubu olarak planlandı. Grup 1 ve grup 2 hastalarından ameliyat günü, postoperatif 1. ve 3. günlerde MDA, SOD, CAT ve CRP seviyelerini belirlemek için venöz kan örnekleri alındı. Grup 3 'ten ise bir kez kan örneği alındı. Gruplar arası parametrik değişkenlerin ortalamasını karşılaştırmak için Tek Yönlü Anova testi kullanıldı. Grup içi parametrelerin karşılaştırılmasında tekrarlı Anova testi kullanıldı.

Bulgular: Bu çalışmada demografik özellikler ve grupların laparatomi nedenleri değerlendirildi. Grup 1'in 0, 1 ve 3.gün MDA değerleri grup 2 ve grup 3 ile karşılaștırıldığında daha yüksek olduğu görüldü ( $\mathrm{p}<0,0001$ ). Grup 1 ve grup 2'nin 0.gün CAT değerleri ile grup 3'ün CAT değerlerinden düşük oldukları saptandı ( $p<0,0001$ ). Grup 1'in 0 . gün SOD değerleri ile grup 2'nin 0 . gün ve grup 3'ün SOD değerleri karşılaştırıldığında grup 1'in SOD değerlerinin daha düşük olduğu görüldü (p<0,0001). Grup 2'nin 1.gün SOD değerleri grup 3'ten daha düşük bulundu ( $\mathrm{p}<0,0001)$. Grup 1 ve grup 2'nin 0, 1 ve 3. gün CRP değerleri karşılaştırıldığında grup 1'in CRP değerleri grup 2'den daha yüksek olduğu görüldü $(\mathrm{p}<0,0001)$.

Sonuç: Generalize peritonitin şiddetini belirlemede ve tedaviye yanıtı takipte lipid peroksidasyon ürünlerinden olan MDA, antioksidan sistemin üyeleri SOD ve CAT enzim düzeyleri ve akut faz reaktanı olan CRP düzeyinin güvenilir ve kolay ölçülebilen parametreler olabileceği kanaatindeyiz.

Anahtar kelimeler: generalize peritonit, süperoksit dismutaz, katalaz, malondialdehit.

\section{INTRODUCTION}

Most of the surgical patients presenting to the emergency department with acute abdomen symptoms. Generalized peritonitis is the leading cause of acute abdomen. Generalized peritonitis is currently considered to be a systemic infection. Severity of peritonitis is shown by many studies to be effective on morbidity and mortality. In order to follow the course of the severity of peritonitis, some of the parameters used in the postoperative period ${ }^{1}$. However, studies are continuing to make these parameters more specific.

Some of the scoring methods are used to determine the severity of generalized peritonitis. However, it is difficult to make use of these scoring methods because they contain many parameters. Some of these scoring systems are Acute physiology and chronic health evaluation score (APACHE II), simplified acute physiology score (SAPS), Mannheim peritonitis index (MPI) and Altona peritonitis index (PIA). The MPI and PIA are only peritonitis specific scoring systems ${ }^{2,3}$.

Many pathophysiological events develop due to generalized peritonitis. Free oxygen radicals caused by inflammation damage the cell membrane. Free oxygen radicals increase lipid peroxidation. The final product of lipid peroxidation, malondialdehyde (MDA) indirectly shows the amount of free oxygen radicals ${ }^{4,5}$. Superoxide dismutase (SOD) and catalase (CAT) levels are also member of the antioxidant system showing the level of cellular damage ${ }^{6}$. An acute phase reactant $\mathrm{C}$-reactive protein (CRP) used in the diagnosis and treatment of sepsis?. 
In cases of increased oxidative stress, such as peritonitis, it is correlated with the severity of peritonitis, and studies on whether MDA, SOD, CAT and CRP levels are usable parameters in the monitoring of peritonitis severity are ongoing. In this study, we aimed to show the validity of these parameters.

\section{METHODS}

This prospective, randomized and controlled trial was conducted in the Department of General Surgery of the Dicle University Medical Faculty. The faculty's ethics committee for clinical research approved the study at March 2008 and numbered 43, and written informed consent was obtained from the participants. Patients over the age of 18 who were scheduled for emergency or elective or healhty individual between March 2008 and September 2008 were considered eligible, and a sum of 150 patients were recruited for this study. In our study, patients with the factors that affect MDA, SOD, CAT and CRP levels were excluded. These factors; smokers ${ }^{8,9}$, cancer patients ${ }^{10,11}$, the diagnosis of patients with malignant hematological disease ${ }^{12}$ and patients who suffered near-term organophosphate were not included in the study ${ }^{13,14}$. This study was planned as three groups $(n=50)$;

Group 1: Patients operated for generalized peritonitis in emergency condition.

Group 2: Patients operated in elective condition and without peritonitis.

Group 3: Control group- healthy individuals.

\section{Study Design}

We evaluated patients participating in the study as three groups. Group $1(n=50)$ consisted of patients with acute abdominal symptoms who underwent emergency surgery and confirmed the diagnosis of generalized peritonitis. Group 2 $(n=50)$ consisted of patients with noninflammatory abdominal disease and done abdominal surgery in elective conditions. Group $3(\mathrm{n}=50)$ consisted of healthy individuals as control group. All the treatments needed for patients were performed in the pre and postoperative period.

Blood samples from patients in group 1 and 2 were collected to determine MDA, SOD, CAT and CRP levels at the operation day (day 0). After operation, the same procedures repeated at the hours of 24 (1st day) and 72 (3rd day). The venous blood samples were collected once from group 3. Measurements of blood samples were taken from superficial veins of arms. No complications were recorded during or after blood samples collection.

\section{Laboratory Measurement Methods}

Uchiyama and Mihara method were used for MDA measurement [15,16]. In this method 8.1\% sodium dodecyl sulfate (SDS), $20 \%$ acetic acid, $0.8 \%$ thiobarbituric acid (TBA) and n-butanol were used as reagent. Three cc venous blood taken into whole blood tube kept in proper conditions until working. MDA level was determined spectrophotometrically.

Three cc heparinized venous blood was taken for SOD measurement. Plasma and leukocytes were removed by centrifugation. Erythrocyte was washed two times with saline and hemolyzed with cold deionized water. Hemoglobin concentration of the hemolysate was adjusted to $10 \mathrm{~g} / \mathrm{dl}$ and SOD activity in the hemolysate was measured spectrophotometrically ${ }^{15}$.

Aebi method was used for CAT measurement 15,17. Five cc heparinized venous blood was taken for CAT measurement. Plasma and leukocytes were removed by centrifugation. Erythrocyte was washed two times with saline. The volume of erythrocyte present was hemolyzed with cold deionized water in a volume of 1,5 times its own. Hemoglobin concentration of the hemolysate was adjusted to $5 \mathrm{~g} / \mathrm{dl}$. Concentrated hemolysate was diluted 
with $1 / 1000$ phosphate buffer. CAT activity was measured spectrophotometrically.

Three cc venous blood was taken into the biochemistry tube for CRP measurement. After 15 minutes, it was centrifuged. CRP level was measured in serum separated by nephelometric method (Immage 2528, Germany).

\section{Statistical Analysis}

Statistical package for social sciences (SPSS) for Windows 10.0 program was used for statistical analysis. Averages of groups of dependent variables in the parametric in according to days, Anova test was used for comparison. Subsequently, it was investigated whether there is a significant difference between the mean of repeated measurements was tested.

The outcome of the test results by Mauchly's test of sphericity were evaluated using the analysis results Pillai. Based on this conclusion, statistical significance of the difference between the mean of three measurements was tested. Dependent groups in the analysis of variance to determine the correct origin of the difference, Bonferroni correction (the level of significance $0.05 / 3=0,0167$ ) paired t-test used for multiple comparisons was applied first.

Statistical evaluation of homogeneity of variances in the groups were evaluated using Leven's test. Compliance with the normal distribution of the distribution groups, using Kolmogorov-Smimov (KS) test was evaluated. Comparing the averages of parametric variables between groups, One way Anova test was used. On the other hand, multiple comparisons were calculated using Tukey's HSD and Dunnett test.

\section{RESULTS}

Male and female ratio was equal in the control group and average age was 39,10 $\pm 12,38$. In group 1, 21 of 50 patients were male (42\%), 29 were female (58\%) and average age was 45,40 $\pm 17,86$. In group 2,18 of 50 patients were male
(36\%), 32 were female (64\%) and average age was $42,00 \pm 13,15$. Reasons of operation in patients in group 1; perforated appendicitis (n:26, \%52), perforation of peptic ulcer (n:16, $\% 32$ ), perforation of sigmoid colon (n:2,4\%), perforation of small intestine (n:6, \%12). Causes of surgery in group 2; incisional hernia (n:23,\%46), ventral hernia (n:15, \%30), cholelithiasis (n:10,\%20), ostomy closure (n:2, \%4). Demographic features and cause of laparatomy of all groups shown in table I and table II.

Table I: Demographic features

\begin{tabular}{|l|l|l|l|l|}
\hline \multicolumn{2}{|c|}{} & GROUP 1 & GROUP 2 & GROUP 3 \\
\hline \multirow{2}{*}{ AGE } & $\begin{array}{l}45,40 \\
( \pm 17,86)\end{array}$ & $\begin{array}{l}42,00 \\
( \pm 13,15)\end{array}$ & $\begin{array}{l}39,10 \\
( \pm 12,38)\end{array}$ \\
\hline \multirow{2}{*}{ SEX } & MALE & $21(\% 42)$ & $18(\% 36)$ & $25(\% 50)$ \\
\cline { 2 - 5 } & FEMALE & $29(\% 48)$ & $32(\% 64)$ & $25(\% 50)$ \\
\hline
\end{tabular}

Table II: Causes of laparotomy

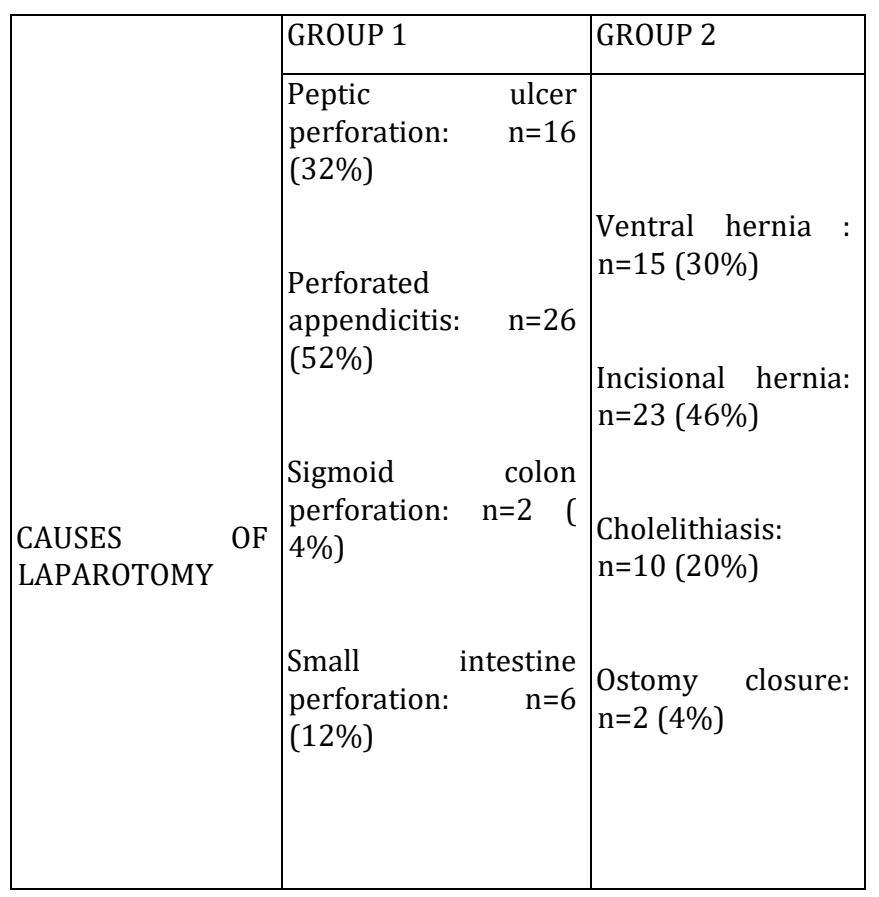

In this study, we reported statistically significant results in comparison of MDA, CAT, SOD and CRP levels at days of 0,1 st and 3rd. 
MDA averages of groups 1 and 2 on the 0 , 1st and 3rd day and group 3 are shown in table II. When the MDA values of group 1 in day 0 were compared with those of group 2 and group 3 in day 0 , MDA values of group 1 were higher than groups 2 and $3(\mathrm{p}<0,0001)$. There was no difference between the MDA values of group 2 in day 0 and the MDA values of group 3 $(\mathrm{p}=0,423)$.

When the MDA values of group 1 in day 1 st were compared with those of group 2 in day 1 st and group 3, MDA values of group 1 were higher than groups 2 and $3(\mathrm{p}<0,0001)$. MDA values of group 2 in day 1 st were compared with group 3 , the difference was found to be statistically significant $(\mathrm{p}<0,0001)$.

When the MDA values of group 1 in day 3rd were compared with those of group 2 in day 3 rd and group 3, MDA values of group 1 were higher than groups 2 and $3(\mathrm{p}=0,0130, \mathrm{p}<0,0001)$. MDA values of group 2 in day 3rd were compared with group 3 as MDA values of group 2 were higher than groups $3(\mathrm{p}<0,0001)$. Comparison of MDA levels of all groups in according to days are in table III.

Table III: Comparison of MDA levels of all groups in according to days.

\begin{tabular}{|l|c|c|c|}
\hline \multirow{2}{*}{ Groups } & \multicolumn{3}{|c|}{ MDA Levels } \\
\cline { 2 - 4 } & Day 0 & Day 1st & Day 3rd \\
\hline Group I & 10,45 & 8,52 & 7,14 \\
\hline Group II & 6,50 & 7,79 & 6,77 \\
\hline Group III & 6,28 & 6,28 & 6,28 \\
\hline
\end{tabular}

Group 1 in 0 , 1st and 3rd day MDA averages showed statistically significant differences (F:209,477; p<0,0001). Also Group 2 in 0, 1st and 3rd day MDA averages showed statistically significant differences ( $F: 124,561 ; p<0,0001)$. The average of MDA values of group 1 and group 2 according to days are shown in graphic 1 .

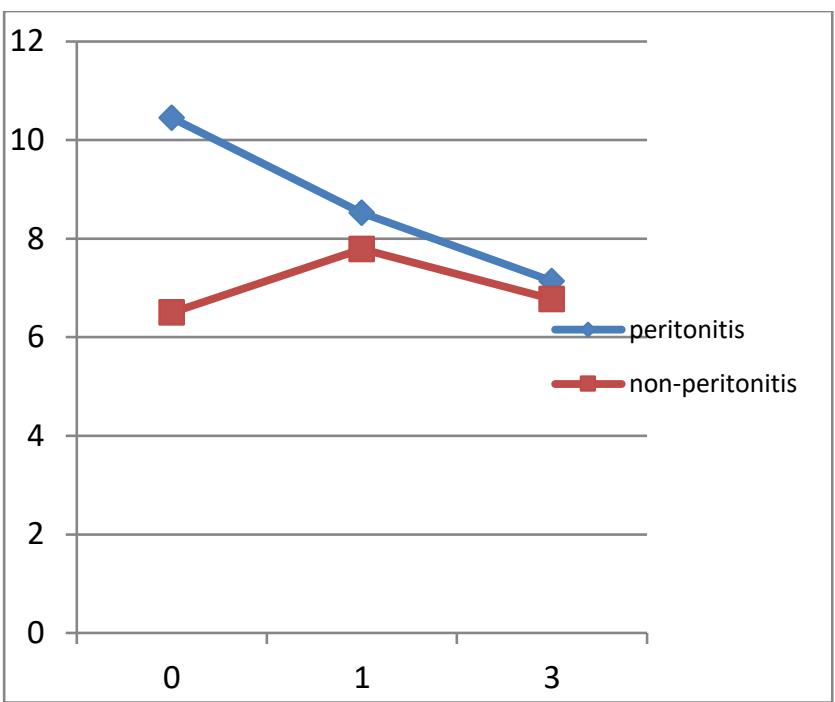

Graphic 1: The average of MDA values of group 1 and group 2 according to days

CAT averages of groups 1 and 2 on the 0,1 st and 3rd day and CAT average of group 3 are shown in table IV. When the CAT values of group 1 in day 0 were compared with those of group 2 in day 0 and group 3, CAT values of group 1 were lower than groups 2 and group $3(\mathrm{p}<0,0001)$. There was no difference between the CAT values of group 2 in day 0 and the CAT values of group $3(p=0,382)$. When the CAT values of group 1 in day 1 st were compared with group 2 in day 1st, the difference was not found to be statistically significant $(p=0,462)$. CAT values of group 2 in day 1 st were compared with group 3 , CAT values of group 2 were lower than groups 3 $(p<0,0001)$. When the CAT values of group 1 in day 3rd were compared with those of group 2 in day 3rd and group 3, CAT values of group 1 were lower than groups 2 and $3(p=0,004 ; p=0,016)$. There was no difference between the CAT values of group 2 in day $3 r d$ and the CAT values of group $3(p=0,890)$. Comparison of CAT levels of all groups in according to days in table IV. 
Table IV: Comparison of CAT levels of all groups in according to days.

\begin{tabular}{|l|c|c|c|}
\hline \multirow{2}{*}{\multicolumn{1}{|c|}{ Groups }} & \multicolumn{3}{|c|}{ CAT Levels } \\
\cline { 2 - 4 } & Day 0 & Day 1st & Day 3rd \\
\hline Group I & 17,01 & 20,40 & 22,82 \\
\hline Group II & 24,30 & 19,90 & 24,88 \\
\hline Group III & 24,70 & 24,70 & 24,70 \\
\hline
\end{tabular}

Group 1 in 0 , 1st and 3rd day CAT averages statistically significant differences (F:251,466; $\mathrm{p}<0,0001$ ). Also Group 2 in 0, 1st and 3rd day CAT averages statistically significant differences (F:55,665; $\mathrm{p}<0,0001$ ). The average of CAT values of group 1 and group 2 according to days shown graphic 2 .

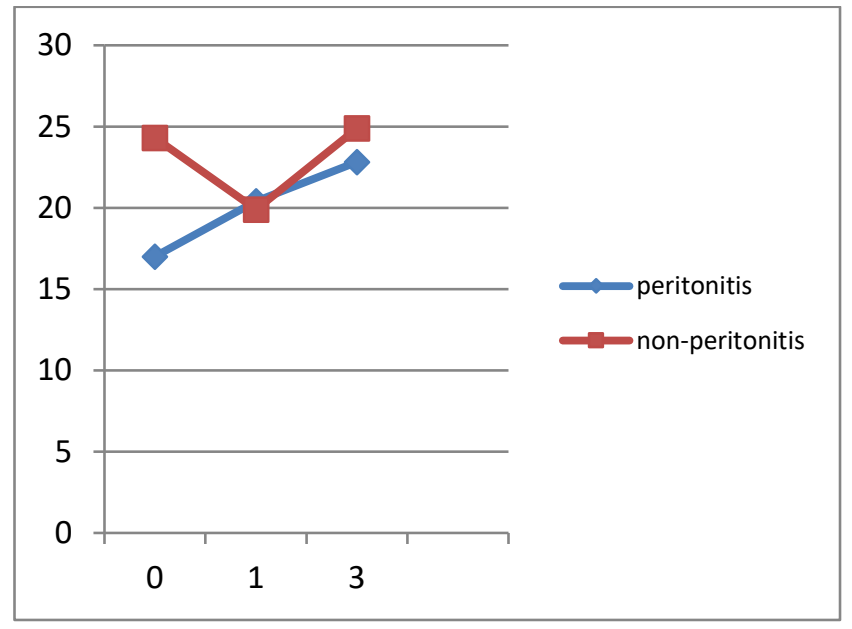

Graphic 2: The average of CAT values of group 1 and group 2 according to days

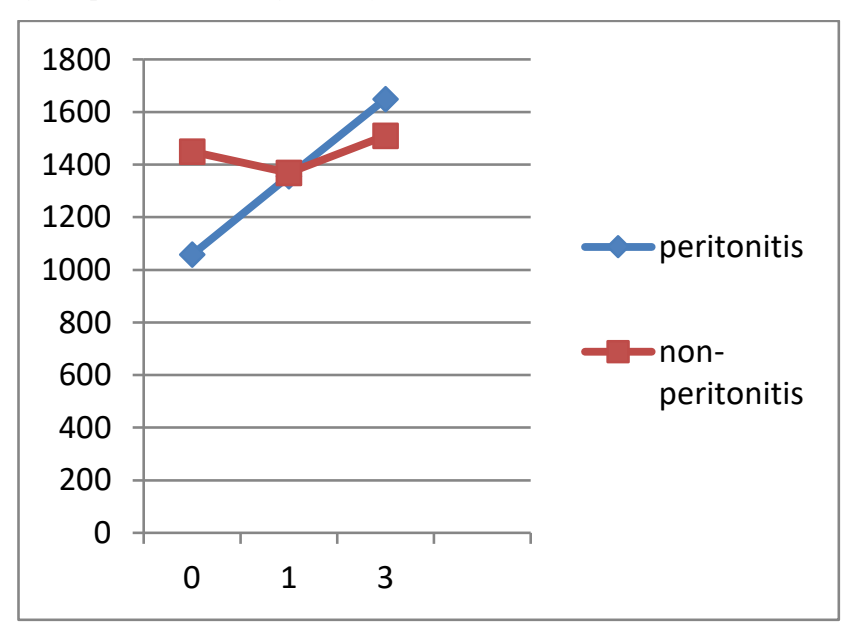

Graphic 3: The average of SOD values of group 1 and group 2 according to days.

SOD averages of groups 1 and 2 on the 0,1 st and 3rd day and SOD average of group 3 are shown in table $\mathrm{V}$. When the SOD values of group 1 in day 0 were compared with those of group 2 in day 0 and group 3, SOD values of group 1 were lower than groups 2 and group $3(\mathrm{p}<0,0001)$. There was no difference between the SOD values of group 2 in day 0 and the SOD values of group $3(p=0,385)$. When the SOD values of group 1 in day 1st were compared with group 2 in day 1st, the difference was not found to be statistically significant $(p=0,785)$. SOD values of group 2 in day 1st lower than group 3 $(p<0,0001)$. When the SOD values of group 1 in day 3rd were compared with those of group 2 and group 3 in day 3rd, SOD values of group 1 were lower than groups 2 and group 3 $(p<0,0001)$. There was no difference between the SOD values of group 2 in day $3 \mathrm{rd}$ and the SOD values of group $3(p=0,648)$. Comparison of SOD levels of all groups in according to days in table V.

Table V: Comparison of SOD levels of all groups in according to days.

\begin{tabular}{|l|c|c|c|}
\hline \multirow{2}{*}{ Groups } & \multicolumn{2}{|l|}{ SOD Levels } \\
\cline { 2 - 4 } & Day 0 & Day 1st & Day 3rd \\
\hline Group I & 1057,46 & 1355,77 & 1649,59 \\
\hline Group II & 1448,72 & 1368,96 & 1509,98 \\
\hline Group III & 1489,10 & 1489,10 & 1489,10 \\
\hline
\end{tabular}

Group 1 in 0 , 1st and 3rd day SOD averages statistically significant differences (F:344,888; $\mathrm{p}<0,0001)$. Group 2 in 0, 1st and 3rd day SOD averages statistically significant differences (F:43,375; p<0,0001). The average of SOD values of group 1 and group 2 according to days shown graphic 3 .

Groups 1 and 2 on the 0 , 1st and 3rd day CRP averages shown in table VI. When the CRP values of group 1 in day 0 , 1st and 3rd were 
compared with group 2 in day 0 , 1st and 3rd; CRP values of group 1 were higher than group 2 $(p<0,0001)$. Comparison of CRP levels of all groups in according to days in table VI.

Table VI: Comparison of CRP levels of all groups in according to days.

\begin{tabular}{|l|c|c|c|}
\hline \multirow{2}{*}{ Groups } & \multicolumn{3}{|c|}{ CRP Levels } \\
\cline { 2 - 4 } & Day 0 & Day 1st & Day 3rd \\
\hline Gruop I & 143.38 & 125.31 & 105.51 \\
\hline Gruop II & 29.85 & 28.70 & 24.98 \\
\hline
\end{tabular}

Group 1 in 0, 1st and 3rd day CRP averages statistically significant differences $(\mathrm{F}=250,435$; $\mathrm{p}<0,0001)$. There was no difference between the CRP values of group 2 in day 0 and in day 1 st $(\mathrm{p}<0,260)$. But in day 0 and 3rd also 1 st day and 3rd day CRP averages of group 2 were statistically significant $(F=45,560 ; p<0,0001)$. The average of CAT values of group 1 and group 2 according to days shown graphic 4 .

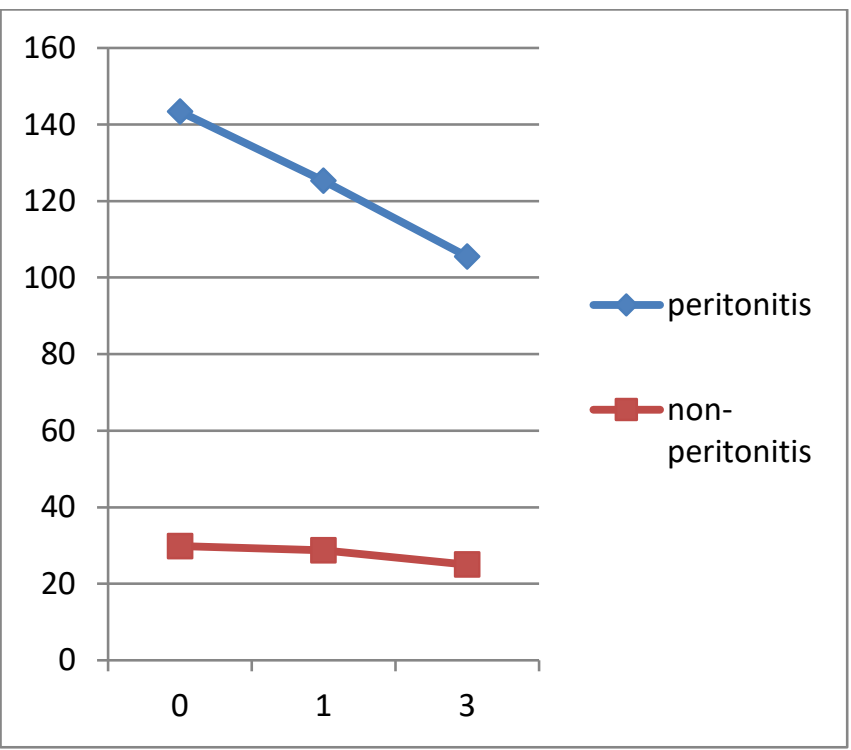

Graphic 4: The average of CRP values of group 1 and group 2 according to days.

\section{DISCUSSION}

Intra-abdominal infections in surgical applications are quite common. Intraabdominal infections, microorganisms and toxins in the peritoneum, and consequently generate an inflammatory response in the abdominal cavity is defined as the accumulation of purulent exudate. This inflammation may be local or generalized on the surface of the peritoneum. Rate of morbidity and mortality of generalized peritonitis is very high. Mortality is present between $1-30 \%$ and delay in diagnosis increased mortality ${ }^{18}$.

Generalized peritonitis is one of the reasons that increase oxidative stress in the body. Increased lipid peroxidation, an indicator of oxidative stress, is mediated the harmful effects of oxidative stress in the body. Lipid peroxidation caused by free radicals are responsible for their harmful effects in the body. There are many defense mechanisms, known as antioxidants, against free oxygen radicals occurring in the body. If the concentration of free oxygen radicals released is much more than the antioxidant capacity of the cleaner system, irreversible cell damage occurs. When oxidative stress increase, lipid peroxidation products also increase in the body ${ }^{19}$.

In a healthy cell, there is a balance between the formation and removal of free radicals. Oxidative stress occurs if the balance is disrupted for any reason and more free radicals are formed or the level of antioxidants decreases. This stress causes serious cell damage if prolonged and severe. Oxidative stress plays an important role in the development of chronic and degenerative diseases and can cause cancer, arthritis, aging, autoimmune diseases, cardiovascular and neurodegenerative diseases. MDA, the final product of lipid peroxidation, is highly cytotoxic and has an inhibitory effect on protective enzymes like SOD, CAT, glutathione peroxidase (GSH-PX) and glutathione (GSH).

With the oxidative stress caused by free radicals and to determine the level of the resulting MDA levels, at least partly determined by the cellular damage that may occur in the body. There are 
many members of the antioxidant system that removes free oxygen radicals from the body as a result of oxidative stress. This study evaluated the response of antioxidant system by SOD and CAT levels. SOD and CAT, as well as generalized peritonitis, take part as a component of the antioxidant system in all cases of infection and inflammation. SOD and CAT levels falls in such cases. CRP is used in the diagnosis of sepsis and in the follow-up of treatment response ${ }^{7,20}$. In this study we used CRP in the diagnosis and follow up of treatment of patients with generalized peritonitis.

In the experimental study conducted by Güzel et al., they investigated the effects of antibiotherapy and intraperitoneal ozone administration on proinflammatory cytokine, antioxidant levels and tissue damage in infectious peritonitis. In this study, MDA as a marker of free oxygen radicals, SOD, CAT and glutathione peroxidase (GSH-Px) levels as indicators of antioxidant system were studied. They compared differences between groups according to treatment protocols as changes in MDA, SOD, CAT and GSH-Px levels. Finally they found that MDA, SOD, CAT and GSH-Px can be used as diagnosis and follow up treatment of infectious peritonitis ${ }^{21}$.

In an experimental study by Erginel et al., they measured MDA, myeloperoxidase (MPO) and GSH-Px activity in experimental peritonitis induced by cecal ligation and puncture in rats. In the peritonitis group, MDA and MPO activity were increased and GSH, which is the parameter of antioxidant system, was found to be low. In addition, MDA and MPO activity decreased in probiotic treated groups, while GSH increased. In addition, mucosal damage decreased in probiotic fed groups ${ }^{22}$.

In an experimental study of Zhang et al., they searched the effect of hydrogen-rich water on acute peritonitis of rat models. MDA and MPO activities in visceral peritoneal tissues were evaluated. MDA and MPO activities were increased due to peritonitis. MDA and MPO activities were decreased in hydrogen-rich water-treated groups ${ }^{23}$.

Cecal ligation and puncture rat model (CLP) versus colon ascendens stent peritonitis (CASP) was studied by Chen et al. In a comparative study with oxidative stress, serum MDA and nitric oxide (NO) levels in CLP and CASP groups were increased at each time point compared to the sham operation group and T-SOD levels decreased significantly 24 .

Corradi et.al. tried to determain the effects of pentoxifylline on intestinal bacterial overgrowth, bacterial translocation and spontaneous bacterial peritonitis in cirrhotic rats with ascites. In this study they analysed Cecal flora and the prevalence of bacterial translocation and spontaneous bacterial peritonitis. They also measured serum and ascitic fluid levels of TNF-alpha and cecal levels of MDA. Finally, they found significantly reduced cecal mucosal levels of malondialdehyde compared to placebo ${ }^{25}$.

Kumar et. al. in their study, 45 patients were operated due to secondary peritonitis were followed prospectively. Increased superoxide radical levels in parallel with the severity of the disease and correspondingly decreased levels of SOD and catalase have identified. However, after the 3rd surgery and measurements carried out on days, no relationship was found between surgical treatment and the parameters established ${ }^{26}$.

In an experimental study of Fujimura et. al, it was created in experimental peritonitis in the first group of rats with cecal ligation and perforation. The second group of rats as the control group were investigated the impact of experimental peritonitis and diaphragmatic contractility. In this study, measured as an indicator of antioxidant status, SOD and catalase was significantly lower than control group created peritonitis. MDA levels, as an indicator 
of oxidative stress, were found significantly increased in experimental group than the control group's MDA levels ${ }^{27}$.

Ayrık et al. reported that leukocyte count, percentage neutrophil ratio and CRP concentration could help in the diagnosis and treatment of appendicitis, and especially in CRP levels, cut values could be helpful in determining the surgical method to be selected and determining the incision to be selected ${ }^{28}$.

Moon et al. performed peritoneal dialysis in patients with peritonitis and CRP and white blood cell counts in a study. They reviewed 117 patients retrospectively. They concluded that serial CRP measurements may help to illustrate the possible complications ${ }^{29}$.

In our study, the patients who had increased oxidative stress, preoperative period the parameters of antioxidant system SOD and CAT levels measured low. The last product of lipid peroxidation MDA level and an acute phase reactant and inflammation marker CRP level measured high. After surgery and treatment SOD and CAT levels are increased unlike MDA and CRP levels are decrease. These results are consistent with other studies and support each other. Scoring methods such as MPI, API can be used to determine the severity of generalized peritonitis. But these methods contains many parameters. Therefore, it is difficult to determine the severity of peritonitis by scoring methods and to monitor the response to treatment. Instead of these methods, we can use MDA, SOD, CAT and CRP are easier to measure.

In conclusion; to determine the severity of generalized peritonitis and monitoring the response to treatment, we think that MAD, SOD, CAT and CRP are reliable parameters.

Ethics Committee Approval: The faculty's ethics committee for clinical research approved the study at March 2008 and numbered 43, and written informed consent was obtained from the participants.
Declaration of Conflicting Interests: The authors declare that they have no conflict of interest.

Financial Disclosure: No financial support was received.

\section{REFERENCES}

1. Schwarts S (çeviri:Şen D.) İntraabdominal Enfeksiyonlar. In: Solomkin JS, Wittman DW, West MA, Barie PS (eds) (çeviri editörü: Geçim E). Cerrahinin İlkeleri (7thEd.) İstanbul.1999.p.1537-76.

2. Ertekin C, Karın içi enfeksiyonlar. In: Kalaycı G (eds), Genel cerrahi-1, İstanbul.2002.p. 21757

3. Witmann DH, Teichmann W, Müler M. Development and validation of peritonitis indices Altona. Langenbecks Arch Chir.1987.p. 834-5.

4. Yagi K. Lipid Peroxidase and Human Diseases. Chemistry And Physics of Lipids. 1987; 45(2-4): p.337-51.

5. Mercan U.Toksikolojide Serbest Radikallerin Önemi. YYU Vet. Fak. Derg. 2004.15.p.91-6.

6. Şimşek F. Serbest Oksijen Radikalleri, Antioksidanlar ve Lipid Peroksidayonu. Türkiye Klinikleri J Pediatri. 1999; 8.p.42-7.

7. Yücel T, Gönüllü D, Güçlü S. et al. Normobarik Oksijenin Deneysel Peritonitin Tedavisindeki Yeri ve Tedavinin İzlenmesinde Rektal Ateș, Lökosit, CRP ve Prokalsitoninin Etkinliği. Ulusal Travma Acil Cerrahi Derg.2008;14.p.14-20.

8. Ulubaş F.Ç.B, Eryılmaz T, Bilgin G. Sigara İçenlerde Lipid Peroksidayonu, Antioksidan Aktivite ve Solunum Fonksiyon Testler. Türkiye Klinikleri Tıp Bilimleri Dergisi 2002; 22.p.29296.

9. T Sisinta, B Wispriyono, H Kusnoputranto. Cigarette Smoke Exposure and Oxidative Stress in Junior High School Children. Journal of 
International Dental \& Medical Research. 2019; 12. P.372-6.

10. Yarıktaş M, Döner F, Doğru H, ve ark. BaşBoyun Malign Tümörlerinde MDA düzeyleri ve antioksidan enzim aktiviteleri. Süleyman Demirel Üniversitesi (SDÜ) Tıp Fak. Derg.2003; 10.p.65-7.

11. Sohail H, Ashafaq M. Oxidative Stress and Anti-oxidants in Pre and Post-operative Cases of Breast Carcinoma. Turk J Pharm Sci 2018; 15.p.354-59.

12. Menteşe A, Erkut N, Demir S, et al. Autoantibodies Against Carbonic Anhydrase I and II in Patients with Acute Myeloid Leukemia. Turk J Haematol. 2017; 34.p.307-13.

13. Gökalp 0, Karakoyun I, Kaleli S, Özer M.K, Gültekin F. Chlorpyrifos Ethyl'in Rat pankreası Üzerine Etkisi. S.D.Ü Tıp Fak. Derg.2005;12.p.19-22.

14. Rahmadani N.M.N, Rachmawati D.A, Elfiah U. The Difference of Plasma Malondialdehyde (MDA) Level in Farmers Using Chemical Pesticides and Farmers Using Organic Pesticides. Journal of Agromedicine and Medical Science.2018; 4.p.165-70.

15. Obay B,D. Deneysel Serebral İskemide Antioksidan Savunma Sistemi ve Serbest Radikal Temizleyicilerin Rolü, Doktora Tezi, Dicle Üniversitesi Tıp Fak. Fizyoloji ABD, 1999.

16. Uchiyama M, Mihara M. Determination of malondialdehyde precursor in tissue by thiobarbituric acit test avaleyt biochem,1978; 86.p.271-78.

17. Aebi H.Catalase in vitro. Methods in enzymology.1984; 86.p.271-78.

18. Wittman D.İntraabdominal İnfeksiyonlar. İn: Sayek İ.(eds).Temel Cerrahi 2 (2nd ed.) 1996. p.1408-33.

19. Shinde A, Ganu J, Naik P. Effect of Free Radicals \& Antioxidants on Oxidative Stress
Journal of Dental \& Allied Sciences 2012; 1.p.636.

20. Smith R.P,Lipworth B.J. C-reactive Protein in Simple Community-Acquired Pneumonia. Chest J. 1995; 107.p.1028-31.

21. Guzel Ö, Gulcubuk A, Yildar E, et.al. Effects of antibiotic and intra-peritoneal ozone administration on proinflammatory cytokine formation, antioxidant levels and abdominal organ functions in the treatment of experimentally generated infectious peritonitis in rabbits. Veterinarni Medicina 64, 2019; 08.p.348-61.

22. Erginel B, Aydin F.A, Erginel T. et. al. Antioxidant Effects of Probiotics in Experimentally Induced Peritonitis. Published Online: $\quad 19 \quad$ Jan 2016 https://doi.org/10.1089/sur.2015.072.

23. Zhang J, Wu Q, Song $\mathrm{S}$ et.al. Effect of hydrogen-rich water on acute peritonitis of rat models. International Immunopharmacology 2014; 21. p. 94-101.

24. Chenorcid L, Cao D, Liu E, et al. Rat Model of Cecal Ligation and Puncture versus Colon Ascendens Stent Peritonitis: Comparative Study for Oxidative Stress. Advances in Infectious Diseases. 2017; 7.p. 80-92.

25. Corradi F, Brusasco C, Fernández J. et al. Effects of pentoxifylline on intestinal bacterial overgrowth, bacterial translocation and spontaneous bacterial peritonitis in cirrhotic rats with ascites. Digestive and Liver Disease J.of Gastroenterology and Hepatology. 2012; 44.p.239-44.

26. Kumar Y, Singh G, Davidson R.B. Free Radical and Antioxidant Levels in Patients with Secondary Peritonitis and Their Prognostic Signifiance. Dig Surg 2007; 24.p.331-7.

27. Fujimara N, Sumita S, Aimono M. et al. Effect of Free Radical Scavengers on Diaphragmatic Contractility in Septic Peritonitis. American 
Journal of Respiratory and Critical Care Medicine.2000; 162.p.2159-65.

28. Ayrık C, Karaaslan U, Dağ A, et al. Predictive Value of Leucocyte Count, Neutrophil Percent and C-Reactive Protein Concentration "Cut-Off Value" On The Diagnose Of Appendicitis. Ulus Travma Acil Cerrahi Derg. 2016; 22.p.76-83.
29. Moon S.J, Han S.H, Kim D.K, et al. Risk Factors for Adverse Outcomes After Peritonitis-Related Technique Failure. Peritoneal Dialysis International. 2008; 28.p.352-60. 